\title{
Spatial analysis of deaths from pulmonary tuberculosis in the city of São Luís, Brazil*
}

\author{
Análise espacial dos óbitos por tuberculose \\ pulmonar em São Luis, Maranhão
}

\section{Marcelino Santos-Neto, Mellina Yamamura, Maria Concebida da Cunha Garcia, Marcela Paschoal Popolin, Tatiane Ramos dos Santos Silveira, Ricardo Alexandre Arcêncio}

\begin{abstract}
Objective: To characterize deaths from pulmonary tuberculosis, according to sociodemographic and operational variables, in the city of São Luís, Brazil, and to describe their spatial distribution. Methods: This was an exploratory ecological study based on secondary data from death certificates, obtained from the Brazilian Mortality Database, related to deaths from pulmonary tuberculosis. We included all deaths attributed to pulmonary tuberculosis that occurred in the urban area of São Luís between 2008 and 2012 . We performed univariate and bivariate analyses of the sociodemographic and operational variables of the deaths investigated, as well as evaluating the spatial distribution of the events by kernel density estimation. Results: During the study period, there were 193 deaths from pulmonary tuberculosis in São Luís. The median age of the affected individuals was 52 years. Of the 193 individuals who died, 142 (73.60\%) were male, 133 (68.91\%) were Mulatto, 102 (53.13\%) were single, and $64(33.16 \%)$ had completed middle school. There was a significant positive association between not having received medical care prior to death and an autopsy having been performed $(p=0.001)$. A thematic map by density of points showed that the spatial distribution of those deaths was heterogeneous and that the density was as high as 8.12 deaths $/ \mathrm{km}^{2}$. Conclusions: The sociodemographic and operational characteristics of the deaths from pulmonary tuberculosis evaluated in this study, as well as the identification of priority areas for control and surveillance of the disease, could promote public health policies aimed at reducing health inequities, allowing the optimization of resources, as well as informing decisions regarding the selection of strategies and specific interventions targeting the most vulnerable populations.
\end{abstract}

Keywords: Tuberculosis, pulmonary/mortality; Communicable disease control; Spatial analysis.

\section{Resumo}

Objetivo: Caracterizar os óbitos por tuberculose pulmonar em São Luís (MA) segundo variáveis sociodemográficas e operacionais e descrever sua distribuição espacial. Métodos: Estudo ecológico e exploratório baseado em dados secundários oriundos das declarações de óbitos por tuberculose pulmonar do Sistema de Informação sobre Mortalidade. Foram incluídos todos os óbitos por tuberculose pulmonar ocorridos na zona urbana de São Luís entre 2008 e 2012. Foram realizadas análises univariadas e bivariadas das variáveis sociodemográficas e operacionais dos óbitos investigados e a distribuição espacial dos eventos por kernel density estimation. Resultados: No período estudado, foram registrados 193 óbitos. A mediana de idade foi de 52 anos. Dos 193 indivíduos, $142(73,60 \%)$ eram do sexo masculino, $133(68,91 \%)$ da raça/cor parda, $102(53,13 \%)$ eram solteiros, e $64(33,16 \%)$ haviam completado o ensino fundamental. Observou-se que não ter recebido assistência médica antes do óbito teve uma associação estatisticamente significativa com a realização de necropsia $(p=0,001)$. 0 mapa temático por densidade de pontos demonstrou uma heterogeneidade na distribuição espacial dos óbitos, com taxas de até 8,12 óbitos $/ \mathrm{km}^{2}$. Conclusões: As características sociodemográficas e operacionais dos óbitos por tuberculose pulmonar evidenciadas nessa investigação, bem como a identificação dos locais prioritários para o controle e a vigilância da doença, poderão auxiliar a gestão pública na diminuição das iniquidades em saúde e permitir uma otimização dos recursos, fornecendo subsídios para a escolha de estratégias e intervenções específicas direcionadas às populações mais vulneráveis.

Descritores: Tuberculose pulmonar/mortalidade; Controle de doenças transmissíveis; Análise espacial.

\footnotetext{
*Study carried out at the University of São Paulo at Ribeirão Preto School of Nursing, Ribeirão Preto, Brazil. Correspondence to: Marcelino Santos Neto. Rua Urbano Santos, s/n, CEP 65900-410, Imperatriz, MA, Brasil. Tel. 5599 3221-7600. E-mail: marcelinosn@gmail.com

Financial support: This study received financial support from the Coordenação de Aperfeiçoamento de Pessoal de Nível Superior (CAPES, Office for the Advancement of Higher Education) and the Fundação de Amparo à Pesquisa do Estado de São Paulo (FAPESP, São Paulo Research Foundation; Grant no. 13/03756-9).
}

Submitted: 31 January 2014. Accepted, after review: 9 July 2014. 


\section{Introduction}

The prevalence of and mortality from tuberculosis have declined worldwide, and most countries are likely to achieve the goal of reducing tuberculosis prevalence and mortality by $50 \%$ by 2015 in comparison with 1990 rates. ${ }^{(1)}$ The World Health Organization has launched a new challenge: the elimination of tuberculosis by 2050. (1) Tuberculosis is the second leading cause of death from an infectious disease, accounting for approximately 1.3 million deaths worldwide in 2012; this demonstrates the severity of tuberculosis, especially in the 22 countries that collectively account for $80 \%$ of the disease burden. ${ }^{(2)}$

Brazil ranks 16th among the countries with the highest number of cases, the tuberculosis incidence and mortality rates in 2012 being $36.1 / 100,000$ population and 2.4/100,000 population, respectively. ${ }^{(2)}$ Brazil has faced major challenges to achieving the ambitious goal of eliminating the disease. For example, in the city of São Luís, which is one of the priority cities for tuberculosis control in the country, ${ }^{(3)}$ the tuberculosis incidence and mortality rates in 2012 were 53.1/100,000 population and 3.9/100,000 population, respectively, ${ }^{(4)}$ indicating limited access to diagnosis and health care, as well as poor treatment adherence. ${ }^{(3)}$

Given that pulmonary tuberculosis (PTB) is transmissible, tuberculosis control measures should prioritize PTB over other clinical presentations. In addition, PTB is a preventable cause of death, meaning that deaths from PTB can be prevented by appropriate health promotion, protection, and recovery measures implemented in local health care systems. ${ }^{(5)}$

Studies of deaths from tuberculosis currently represent an important method for understanding the difficulties that health care systems face in controlling the disease and for identifying the most vulnerable groups. However, a literature review has shown that few studies have examined the spatial distribution of deaths from tuberculosis in the country. ${ }^{(6)}$

Although access to health care has improved in Brazil, an optimal level of equity has yet to be achieved, inequality resulting in health outcomes that are not always fair or acceptable, ${ }^{(7)}$ e.g., deaths from PTB. Therefore, the present study is evidently relevant, given that it can aid in strengthening health systems and services so that the problem of tuberculosis can be faced.
The objectives of the present study were to characterize, on the basis of sociodemographic and operational variables, deaths from PTB in the city of São Luís in the 2008-2012 period; to determine whether there were differences between the PTB deaths that were confirmed by autopsy and those that were not in terms of the study variables; and to determine the geographic areas of the city in which PTB deaths were most common.

\section{Methods}

This was an exploratory ecological study conducted in the city of São Luís (Figure 1), which is located in northern Maranhão. The metropolitan area of São Luís comprises the municipalities of Paço do Lumiar, Raposa, and São José de Ribamar, among others. Specifically, the city of São Luis is located on the western portion of São Luís 1sland, between $\mathrm{S}^{\circ} 2^{\circ} 28$ '21" W44 $07^{\prime} 49^{\prime \prime}$ and S02 ${ }^{\circ} 39^{\prime} 34^{\prime \prime}$ W44 $4^{\circ} 20^{\prime} 59^{\prime \prime}$; it has an area of $834.780 \mathrm{~km}^{2}$ and a population of $1,014,837$ inhabitants. $^{(8)}$

The study population consisted of individuals whose underlying cause of death was PTB (International Classification of Diseases, 10th revision-1CD-10-codes A15.0-A15.3 and A16.0A16.2) and who resided in the urban area of São Luis between 2008 and 2012 .

Data were collected in July of 2013 from the Sistema de Informação sobre Mortalidade (SIM, Brazilian National Mortality Database) of the São Luís Municipal Department of Health Office for Epidemiological and Health Surveillance. Individuals who died in São Luís but resided elsewhere were excluded, as were those who died from clinical presentations other than PTB.

The variables of interest were obtained from death certificates and included sociodemographic characteristics (including age, gender, skin color/ ethnicity, marital status, level of education, and occupation) and operational variables (including place of death, medical care prior to death, autopsy, underlying cause of death, and physician completing the death certificate).

After having analyzed the consistency of the data collected, we converted the data to STATISTICA, version 10.0 (StatSoft Inc., Tulsa, OK, USA), and the variables were regrouped and analyzed. Regarding the variable age, the individuals who died from PTB in São Luís were categorized on the basis of the median age, 

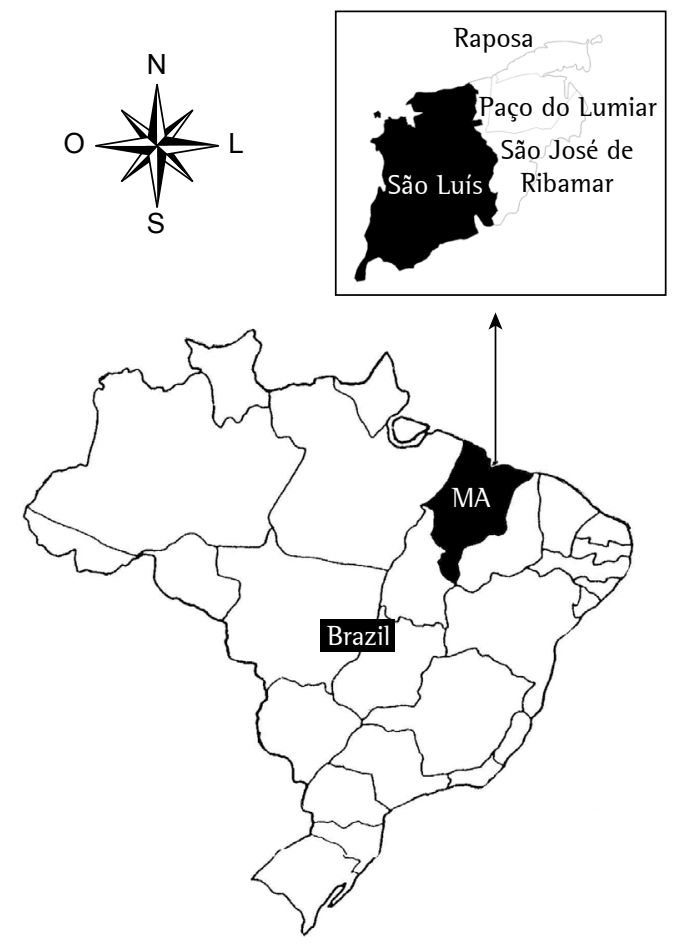

Figure 1 - Map of Brazil showing the city of São Luís, in the state of Maranhão (MA). Adapted from Brazilian Institute of Geography and Statistics geographic databases. ${ }^{(8)}$

being therefore classified by age above or below the median.

Using the same program, we subsequently performed a bivariate analysis cross-referencing the independent variables (sociodemographic and operational variables) with the dependent variable "death confirmed by autopsy" (yes, no). After that, we used the chi-square test for analysis of proportions. The probability of a type 1 error was set at 5\%. At that point, death certificates that were incomplete or on which the cause of death was recorded as unknown were excluded from the study.

In order to determine the areas in which deaths from PTB were most common, we used geocoding (with the freeware TerraView, version 4.2.2, developed by the Brazilian National Institute for Space Research), by standardizing the addresses of the individuals residing in the urban area of São Luís and comparing the addresses with a street segment digital map (StreetBase ${ }^{\circledR}$; Imagem, São José dos Campos, Brazil) in World Geodetic System 1984 latitude and longitude, available in shapefile format.
We subsequently performed kernel density estimation, which consists of an exploratory interpolation generating a density surface for visual identification of "hotspots"; the points within a region of influence are counted and then weighted by the distance between each point and the location of interest. ${ }^{(9)}$

$A$ radius of $1,000 \mathrm{~m}$ being taken into consideration, a thematic map of the distribution of PTB deaths by home address was generated in ArcGIS software, version 10.2 (Esri, Redlands, CA, USA).

The present study was approved by the Research Ethics Committee of the University of São Paulo at Ribeirão Preto School of Nursing (Ruling no. 259,935, May 8, 2013).

\section{Results}

We identified 221 deaths from tuberculosis. Of those, 193 were related to PTB. Of those, 190 (98.44\%) were deaths of individuals whose death certificates listed PTB as the underlying cause of death, without mention of bacteriological or histological confirmation (ICD-10 16.2); 1 $(0.52 \%)$ was the death of an individual whose death certificate read "pulmonary tuberculosis, no bacteriological or histological examination having been performed" (ICD-10 A16.1); 1 (0.52\%) was the death of an individual whose death certificate read "pulmonary tuberculosis confirmed by histological examination" (ICD-10 A15.2); and $1(0.52 \%)$ was the death of an individual whose death certificate read "pulmonary tuberculosis confirmed by sputum smear microscopy, with or without culture" (ICD-10 A15.0).

The median age of the individuals who died in São Luís was 52 years, the youngest being 16 years old and the oldest being 93 years old.

Table 1 shows the sociodemographic and operational characteristics of the individuals who died from PTB in São Luis, the results being presented in decreasing order of frequency. Most of the individuals who died were male $(n=142$; $73.60 \%)$, Mulatto ( $n=133 ; 68.91 \%)$, and single $(n=102 ; 53.13 \%)$. A greater proportion of the individuals had had 9 years of schooling $(n=$ $64 ; 33.16 \%$ ), and most were housekeepers (n $=79 ; 40.93 \%$ ). With regard to the operational variables, most of the deaths occurred in a hospital ( $n=143 ; 74.08 \%$ ), and most of the individuals received medical care prior to death $(n=162$; $83.94 \%$, including those requiring hospitalization). 
Table 1 - Sociodemographic and operational characteristics of individuals who died from pulmonary tuberculosis. São Luís, Brazil, 2008-2012.

\begin{tabular}{|c|c|c|}
\hline Variable & $\mathrm{n}$ & $\%$ \\
\hline \multicolumn{3}{|l|}{ Age } \\
\hline$\leq 52$ years & 98 & 50.78 \\
\hline$>52$ years & 95 & 49.22 \\
\hline \multicolumn{3}{|l|}{ Gender } \\
\hline Male & 142 & 73.60 \\
\hline Female & 51 & 26.40 \\
\hline \multicolumn{3}{|l|}{ Skin color/ethnicity } \\
\hline Brown (Mulatto) & 133 & 68.91 \\
\hline White (Caucasian) & 35 & 18.13 \\
\hline Black (African) & 24 & 12.44 \\
\hline Yellow (Asian) & 1 & 0.52 \\
\hline \multicolumn{3}{|l|}{ Marital status } \\
\hline Single & 102 & 53.13 \\
\hline Married & 58 & 30.21 \\
\hline Widowed & 21 & 10.94 \\
\hline Divorced & 5 & 2.60 \\
\hline Steady partner & 4 & 2.08 \\
\hline No data & 2 & 1.04 \\
\hline \multicolumn{3}{|l|}{ Level of education } \\
\hline 9 years of schooling & 64 & 33.16 \\
\hline High school & 50 & 25.91 \\
\hline$<9$ years of schooling & 40 & 20.72 \\
\hline College (incomplete) & 24 & 12.44 \\
\hline No schooling & 9 & 4.66 \\
\hline College (complete) & 4 & 2.08 \\
\hline No data & 2 & 1.04 \\
\hline \multicolumn{3}{|l|}{ Occupation } \\
\hline Housekeeper & 79 & 40.93 \\
\hline Other & 30 & 15.54 \\
\hline Rural worker & 27 & 13.99 \\
\hline Homemaker & 25 & 12.95 \\
\hline Pensioner & 16 & 8.29 \\
\hline Unemployed & 9 & 4.66 \\
\hline Student & 5 & 2.60 \\
\hline No data & 2 & 1.04 \\
\hline \multicolumn{3}{|l|}{ Place of death } \\
\hline Hospital & 143 & 74.08 \\
\hline Home & 40 & 20.72 \\
\hline Street & 7 & 3.64 \\
\hline Other & 3 & 1.56 \\
\hline \multicolumn{3}{|l|}{ Medical care } \\
\hline Yes & 162 & 83.94 \\
\hline No & 30 & 15.54 \\
\hline No data & 1 & 0.52 \\
\hline \multicolumn{3}{|l|}{ Autopsy } \\
\hline No & 108 & 55.95 \\
\hline Yes & 54 & 28.00 \\
\hline No data & 31 & 16.05 \\
\hline \multicolumn{3}{|l|}{ Death certified by } \\
\hline Substitute physician & 70 & 36.27 \\
\hline Mortality Surveillance System & 51 & 26.42 \\
\hline Attending physician & 45 & 23.31 \\
\hline Other & 24 & 12.44 \\
\hline Institute of Forensic Medicine & 3 & 1.56 \\
\hline TOTAL & 193 & 100.00 \\
\hline
\end{tabular}

Most of the deaths were certified by a substitute physician ( $n=70 ; 36.27 \%)$. Most of the individuals who died did not undergo an autopsy $(n=108$; 55.95\%). Of the death certificates, 31 (16.05\%) had no information as to whether an autopsy had been performed.

Table 2 shows the distribution of PTB deaths (an autopsy having been performed or not) according to the sociodemographic and operational characteristics. The variable skin color/ethnicity was found to be significantly associated with an autopsy having been performed ( $p=0.003)$. An autopsy having been performed was also found to be significantly associated with death outside the hospital, e.g., at home or in the street ( $p=$ 0.001). Likewise, the variable "not having received medical care prior to death" was found to be significantly associated with an autopsy having been performed $(p=0.001)$.

An autopsy having been performed was found to be significantly associated with death certified by the Mortality Surveillance System ( $p=0.001)$. Most of the deaths after which an autopsy was not performed were certified by an attending physician or by a substitute physician $(p=0.001)$.

During the study period, 183 deaths from PTB (95\%) were geocoded. Of the cases that were not geocoded, $4(2 \%)$ had incomplete addresses in the SIM and $2(1 \%)$ lived in the rural area of São Luís.

Figure 2 shows a thematic map of the distribution of PTB deaths in the urban area of São Luís by home address. The map highlights areas in which mortality rates were highest (deaths per $\mathrm{km}^{2}$ ). These areas are represented by darker shades, denoting a heterogeneous spatial distribution of PTB deaths in São Luís during the study period.

The hotspots for PTB deaths are concentrated in the districts of Anjo da Guarda, Liberdade, João de Deus, Bequimão, Cidade Operária, Coroadinho, Monte Castelo, and Centro (city center), the density ranging from 2.53 deaths $/ \mathrm{km}^{2}$ to 8.12 deaths $/ \mathrm{km}^{2}$.

\section{Discussion}

Although PTB is preventable, curable, and easily diagnosed-and although the Brazilian Unified Health Care System guarantees universal access to tuberculosis treatment, thus facilitating (at least to a certain extent) access to health services-4,500 people in Brazil die from the 
Table 2 - Deaths from pulmonary tuberculosis (with or without autopsy confirmation), distributed according to sociodemographic and operational variables. São Luís, Brazil, 2008-2012. ${ }^{a}$

\begin{tabular}{|c|c|c|c|}
\hline \multirow[t]{2}{*}{ Variable } & \multicolumn{2}{|c|}{ Autopsy $^{\mathrm{b}}$} & \multirow[t]{2}{*}{$\mathrm{p}$} \\
\hline & Yes & No & \\
\hline \multicolumn{4}{|l|}{ Age } \\
\hline$\leq 52$ years & $23(14.20)$ & $58(35.80)$ & \multirow[t]{2}{*}{0.182} \\
\hline$>52$ years & $31(19.14)$ & $50(30.86)$ & \\
\hline \multicolumn{4}{|l|}{ Gender } \\
\hline Male & $39(24.07)$ & $83(51.23)$ & \multirow[t]{2}{*}{0.519} \\
\hline Female & $15(9.26)$ & $25(15.43)$ & \\
\hline \multicolumn{4}{|l|}{ Skin color/ethnicity } \\
\hline White (Caucasian) & $4(2.47)$ & $27(16.67)$ & \multirow[t]{4}{*}{0.003} \\
\hline Black (African) & $3(1.85)$ & $17(10.49)$ & \\
\hline Yellow (Asian) & $0(0.00)$ & $1(0.62)$ & \\
\hline Brown (Mulatto) & $47(29.01)$ & $63(38.89)$ & \\
\hline \multicolumn{4}{|l|}{ Marital status ${ }^{c}$} \\
\hline Single & $31(19.38)$ & $50(31.25)$ & \multirow[t]{5}{*}{0.708} \\
\hline Married & $15(9.38)$ & $38(23.75)$ & \\
\hline Widowed & $5(3.13)$ & $13(8.13)$ & \\
\hline Divorced & $1(0.63)$ & $4(2.50)$ & \\
\hline Steady partner & $1(0.63)$ & $2(1.25)$ & \\
\hline \multicolumn{4}{|l|}{ Level of education ${ }^{c}$} \\
\hline No schooling & $4(2.50)$ & $5(3.13)$ & \multirow[t]{6}{*}{0.547} \\
\hline$<9$ years of schooling & $11(6.88)$ & $22(13.75)$ & \\
\hline 9 years of schooling & $19(11.88)$ & $34(21.25)$ & \\
\hline High school & $16(10.00)$ & $29(18.13)$ & \\
\hline College (incomplete) & $3(1.88)$ & $15(9.38)$ & \\
\hline College (complete) & $0(0.00)$ & $2(1.25)$ & \\
\hline \multicolumn{4}{|l|}{ 0ccupation ${ }^{c}$} \\
\hline Unemployed & $3(1.88)$ & $6(3.75)$ & \multirow[t]{7}{*}{0.227} \\
\hline Homemaker & $11(6.88)$ & $8(5.00)$ & \\
\hline Rural worker & $9(5.63)$ & $14(8.75)$ & \\
\hline Housekeeper & $21(13.13)$ & $46(28.75)$ & \\
\hline Student & $0(0.00)$ & $4(2.50)$ & \\
\hline Pensioner & $0(0.00)$ & $13(8.13)$ & \\
\hline Other & $9(5.63)$ & $16(10.00)$ & \\
\hline \multicolumn{4}{|l|}{ Place of death } \\
\hline Hospital & $13(8.02)$ & $102(62.96)$ & \multirow[t]{4}{*}{0.001} \\
\hline Home & $32(19.75)$ & $6(3.70)$ & \\
\hline Street & $7(4.32)$ & $0(0.00)$ & \\
\hline Other & $2(1.23)$ & $0(0.00)$ & \\
\hline \multicolumn{4}{|l|}{ Medical care } \\
\hline Yes & $29(17.90)$ & $105(64.81)$ & \multirow[t]{2}{*}{0.001} \\
\hline No & $25(15.43)$ & $3(1.85)$ & \\
\hline \multicolumn{4}{|c|}{ Underlying cause of death (ICD-10 code) } \\
\hline 15.0 & $0(0.00)$ & $1(0.62)$ & \multirow[t]{4}{*}{0.675} \\
\hline 15.2 & $0(0.00)$ & $1(0.62)$ & \\
\hline 16.1 & $0(0.00)$ & $1(0.62)$ & \\
\hline 16.2 & $54(33.33)$ & $105(64.81)$ & \\
\hline Death certified by & & & \\
\hline Attending physician & $1(0.62)$ & $28(17.28)$ & 0.001 \\
\hline Substitute physician & $1(0.62)$ & 55 (33.95) & \\
\hline Institute of Forensic Medicine & $3(1.85)$ & $0(0.00)$ & \\
\hline Mortality Surveillance System & 49 (30.25) & $2(1.23)$ & \\
\hline Other & $0(0.00)$ & $23(14.20)$ & \\
\hline
\end{tabular}

ICD-10: International Classification of Diseases, 10th revision. ${ }^{\mathrm{a}} \mathrm{N}=162$, except where otherwise indicated. ${ }^{\mathrm{b}} \mathrm{Values}$ expressed as $\mathrm{n}(\%) .{ }^{\mathrm{c}} \mathrm{N}=160$. 


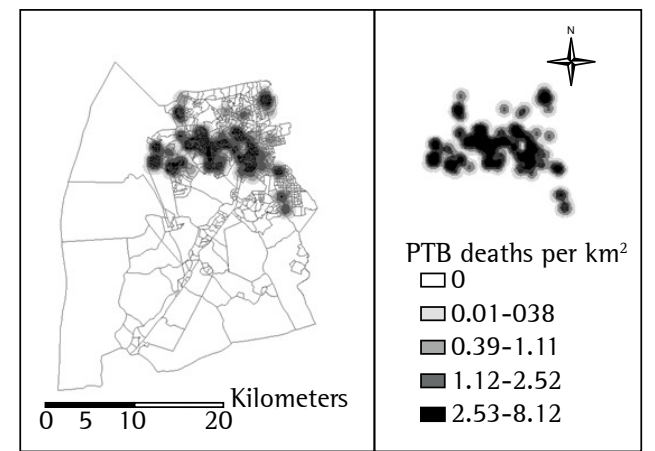

Figure 2 - Dot density map of deaths from pulmonary tuberculosis (PTB) in the urban area of São Luís, Brazil, 2008-2012.

disease. ${ }^{(10)}$ The present study focused on deaths from PTB, which, as evidenced by the literature, is highly lethal and the main transmissible form of tuberculosis. ${ }^{(11)}$

The number of deaths from PTB in São luís was relatively high in comparison with the number of deaths from PTB in other capitals of northeastern Brazil and the country as a whole. ${ }^{(4)}$ We found a significant number of deaths whose underlying cause was recorded as ICD-10 code 16.2, which is consistent with studies conducted in the city of Campo Grande ${ }^{(12)}$ and in the state of Rio de Janeiro, Brazil. ${ }^{(13)}$

This result indicates a major challenge for health care systems, i.e., a critical issue to be overcome; there is a possibility of false-positive results among the deaths whose cause was certified as PTB, given that most of the death certificates had no mention of bacteriological or histological confirmation. This might be due to the fact that the information was not recorded ${ }^{(10)}$ or to the fact that sputum smear microscopy is not prioritized in the hospital setting. ${ }^{(14)}$ This may have been a source of bias in the present study.

With regard to the sociodemographic characteristics of the individuals who died from PTB in São Luis, the results of the present study are consistent with those of other studies, ${ }^{(13-23)}$ in which the proportion of deaths was found to be higher among males, a finding that corroborates reports that PTB is less common in females than in males. This might be due to the fact that males participate in the workforce more than do females and the fact that males use health services less than do females, as well as to the fact that the prevalence of HIV infection, alcoholism, and drug abuse is higher in males. ${ }^{(24,25)}$ However, these variables were not investigated in our study.
The present study focused exclusively on deaths whose underlying cause was reported as being PTB, which is a preventable cause of death. ${ }^{(5)}$ Therefore, deaths associated with but not caused by tuberculosis were not included.

With regard to age and marital status, deaths from PTB were found to be more common among individuals who were 52 years of age or younger and among those who were single, a finding that is consistent with those of studies conducted in the Brazilian states of Mato Grosso do Sul, ${ }^{(12)}$ Minas Gerais, ${ }^{(16)}$ Ceará, ${ }^{(25)}$ and Rio de Janeiro, ${ }^{(13)}$ as well as in Africa. ${ }^{(20)}$

With regard to skin color/ethnicity, the results of the present study are consistent with those of a study conducted in the city of Campo Grande $^{(12)}$ and with those of a study conducted in other priority cities for tuberculosis control in the state of Mato Grosso do Sul, ${ }^{(11)}$ in which most of the deaths occurred in individuals who were Mulatto, ${ }^{(3,15)}$ but inconsistent with those of a study conducted in the city of São Paulo, Brazil, ${ }^{(18)}$ in which most of the deaths occurred in individuals who were White.

With regard to the level of education and occupation, the findings of the present study are consistent with those of other studies, ${ }^{(11,12,16,18)}$ in which illiteracy or a low level of education and low-income jobs were reported as risk factors for PTB; all of the above are risk factors for PTB and are responsible for a higher incidence of the disease, as well as contributing to treatment nonadherence and death. ${ }^{(10)}$

With regard to operational characteristics, approximately $75 \%$ of the deaths analyzed in the present study occurred in a hospital. This is consistent with studies conducted in the Brazilian states of Rio de Janeiro ${ }^{(13)}$ and Mato Grosso do Sul, ${ }^{(11)}$ as well as with a study conducted in the city of São Paulo, ${ }^{(18)}$ all of which showed rates higher than $80 \%$. The death of patients hospitalized for tuberculosis suggests that the primary health care system faces difficulties in management, in providing access to diagnostic resources, in case management, and in referring patients to other health services. ${ }^{(26)}$ Another possible explanation is treatment nonadherence, which predicts the development of multidrugresistant tuberculosis and worsening of the disease; treatment discontinuation can lead to hospitalization when individuals seek health services. ${ }^{(20)}$ 
Analysis of the mortality rates for communicable diseases reflects the efficacy of prevention and control measures, as well as the quality of diagnosis and medical care, being of limited use when there is a high proportion of deaths without medical care or of deaths due to ill-defined causes. ${ }^{(5)}$ In the present study, approximately $15 \%$ of all deaths from PTB occurred without medical care, and, in most cases, no autopsy was performed. However, the records showed that $26 \%$ of the deaths were certified by the Mortality Surveillance System.

Although an autopsy allows the diagnosis of diseases that were not suspected or elucidated before death, it should be used judiciously. ${ }^{(27)}$ In the present study, we found a significant association between not having received medical care prior to death and an autopsy having been performed. We also found that an autopsy was not performed in only $3(1.85 \%)$ of the individuals who died without having received medical attention prior to death.

The findings described above show the importance of a health care system that allows equity of access to health care, thus allowing tuberculosis cases to be diagnosed in a timely manner, especially in the primary health care setting, in order to prevent deaths. Autopsy confirmation of tuberculosis clearly shows the inadequacy of health care systems in reducing social inequalities in health. ${ }^{(28)}$

As is the case with other endemic diseases, tuberculosis is strongly influenced by the environment, and the disease has long been associated with a low socioeconomic status; therefore, there is a need to study the disease and combat it, its spatial distribution being taken into account. ${ }^{(19)}$

The spatial distribution of deaths from PTB (with emphasis on the heterogeneous distribution observed in the city of São Luís) should be considered the starting point of a process of investigation and surveillance that can lead to the identification of problem areas and failures of the health care system to provide health care for the target population.

Our dot density map shows the sites where PTB deaths per $\mathrm{km}^{2}$ are most likely to occur, showing the spatial distribution of hotspots and revealing geographic inequalities related to events occurring in the city. This effectively contributed to the identification of geographic areas in which
PTB deaths occurred and in which preventive/ curative measures are therefore required in order to reorganize health services to meet the health needs of the population.

The areas in which the density of deaths per $\mathrm{km}^{2}$ was highest coincided with areas in which housing conditions and home quality were classified as poor in a study conducted in São Luís. ${ }^{(29)}$ These areas include the following districts: Coroadinho; llhinha; Turu; Anjo da Guarda; Vila Nova; Vila Luizão; Vila Embratel; Liberdade; Sá Viana; Divineia; and parts of Cidade Operária. The aforementioned study ${ }^{(29)}$ showed that unplanned urban growth in São Luís resulted in subnormal areas, classified as lacking public services (most of which are essential).

Curtis $^{(28)}$ reported that health services tend to be ineffective and insufficient in areas in which housing and sanitation are poor, i.e., areas in which social inequality is high. Although we did not investigate the health care facilities in the aforementioned areas, we have reasons to assume that there is a relationship among the deaths from PTB, the areas in which those who died resided, and the health systems and services in those areas.

In Brazil, high social inequality in access to health resources, education, income distribution, sanitation, and other aspects related to the standard of living of the population contributes to differences across social strata regarding the risk of illness ${ }^{(19)}$ and, consequently, the risk of death.

As demonstrated in the present study, the identification of priority areas for tuberculosis control could promote public health policies aimed at reducing health inequalities, allowing the optimization of resources and teams for PTB control in the study setting, as well as informing decisions regarding the selection of strategies and specific interventions targeting the most vulnerable populations.

For diseases for which reporting is mandatory, such as PTB, the use of data available in health information systems allows the monitoring of the problem, aids in the identification of relevant issues, and encourages the search for new interventions for disease control. ${ }^{(26)}$ Therefore, the data collected from the SIM allowed us to observe the dynamics and behavior of PTB in São Luís during the study period. 
As a source of information for the study of deaths in a given area, the SIM has limitations, including underreporting, ${ }^{(10,12)}$ which is one of the consequences of unequal access to health care. Another limitation is missing data on death certificates, complete records being important for health management and planning.

The parameters used in the present study, particularly those used in the definition of the radius for kernel density estimation, were chosen on the basis of empirical knowledge and constitute one of the limitations of the present study. Nevertheless, we sought to choose parameters that contributed to the understanding of the study subject.

Other limitations of the present study are due to its observational design, including interference from spurious variables or confounding factors. We should also take into consideration the ecological fallacy, which is the major limitation of ecological studies; therefore the results cannot be considered at the individual level. Finally, the use of secondary data constitutes yet another limitation of the present study; incomplete or missing data may have contributed to an information bias.

The results of the present study can guide health managers and professionals in identifying priority areas for investment in health care, in order to eliminate preventable deaths from tuberculosis. The present study provides an opportunity to reconsider major clinical practice and environmental issues, as well as allowing us to reflect on the efficacy of public policies in reducing health inequalities and providing social protection to the population.

\section{Acknowledgments}

We would like to thank the São Luís Municipal Department of Health Office for Epidemiological and Health Surveillance for allowing us to conduct the present study and for providing the data for analysis.

\section{References}

1. World Health Organization. The global plan to stop TB 2011-2015: transforming the fight towards elimination of tuberculosis - reprinted with changes, 2011. Geneva: WHO; 2011.

2. World Health Organization. Global tuberculosis report 2013. Geneva: WHO; 2013.

3. Ministério da Saúde. Secretaria de Vigilância em Saúde. Programa Nacional de Controle da Tuberculose. Manual de recomendações para o controle da tuberculose no Brasil. Brasília: Ministério da Saúde; 2011.

4. Ministério da Saúde. Sala de Apoio à Gestão Estratégica. [homepage on the Internet]. Brasilia: SAGE/SUS [cited 2014 Jun 02]. Available from: http://189.28.128.178/sage/

5. Malta DC, França E, Abreu DX, Oliveira H, Monteiro RA, Sardinha LMV, et al. Atualização da lista de causas de mortes evitáveis ( 5 a 74 anos de idade) por intervenções do Sistema Único de Saúde do Brasil. Epidemiol Serv Saúde. 2011;20(3):409-12. http://dx.doi.org/10.5123/ S1679-49742011000300016

6. Mota FF, Vieira-da-Silva LM, Paim JS, Costa Mda C. Distribuição espacial da mortalidade por tuberculose em Salvador, Bahia, Brasil. Cad. Saude Publica. 2003;19(4); 915-22. http://dx.doi.org/10.1590/ S0102-311X2003000400014

7. Organização Pan-Americana da Saúde. Health in the Americas: 2012 Edition. Regional overview and country profiles. Washington: OPAS; 2012.

8. Instituto Brasileiro de Geografia e Estatística [homepage on the Internet]. Brasília: IBGE [cited 2013 Dez 27]. Censo Demográfico 2010. Available from: http://cidades. ibge.gov.br/xtras/perfil.php?lang=Ctcodmun $=211130 \mathrm{cts}$ earch=maranhao|sao-luis

9. Camara G, Carvalho MS. Análise espacial de eventos. In: Druck S, Carvalho MS, Câmara G, Monteiro AV, editors. Análise espacial de dados geográficos. Brasília: EMBRAPA; 2004.

10. de Oliveira GP1, Pinheiro RS, Coeli CM, Barreira D, Codenotti SB. Mortality information system for identifying underreported cases of tuberculosis in Brazil. Rev Bras Epidemiol. 2012;15(3):468-77.

11. Larroque MM. Mortalidade por tuberculose em municípios prioritários do estado de Mato Grosso do Sul [dissertation]. Campo Grande: Universidade Federal do Mato Grosso do Sul; 2011.

12. Espindola LCD. Estudo da mortalidade por tuberculose em Campo Grande - MS, 2001 a 2008 [dissertation]. Rio de Janeiro: Escola Nacional de Saúde Pública; 2010.

13. Selig L, Belo M, Cunha AJ, Teixeira EG, Brito R, Luna $\mathrm{AL}$, et al. Óbitos atribuídos à tuberculose no Estado do Rio de Janeiro. J Pneumol. 2004;30(4):417-24.

14. Cecilio HP, Molena-Fernandes CA, Mathias TA, Marcon SS. Perfil das internações e óbitos hospitalares por tuberculose. Acta Paul Enferm. 2013;26(3):250-55. http://dx.doi.org/10.1590/S0103-21002013000300008

15. Oliveira GP, Torrens AW, Bartholomay P, Barreira D. Tuberculosis in Brazil: last tem years analysis - 20012010. Braz J Infect Dis. 2013;17(2):218-33. http:// dx.doi.org/10.1016/j.bjid.2013.01.005

16. Augusto $\mathrm{CJ}$, Carvalho WS, Gonçalves AD, Ceccato MG, Miranda SS. Characteristics of tuberculosis in the state of Minas Gerais, Brazil: 2002-2009. J Bras Pneumol. 2013;39(3):357-64. http://dx.doi.org/10.1590/ S1806-37132013000300013

17. Moreira CM, Zandonade E, Reynaldo D, Maciel EL. Tuberculosis-related mortality in the state of Espírito Santo, Brazil, 1985-2004. J Bras Pneumol. 2008;34(8):601-6.

18. Lindoso AA, Waldman EA, Komatsu NK, Figueiredo SM, Taniguchi M, Rodrigues LC. Profile of tuberculosis patients progressing to death, city of São Paulo, Brazil, 2002. Rev Saude Publica 2008;42(5):805-12. http:// dx.doi.org/10.1590/S0034-89102008000500004

19. Hino P, da Costa-Junior ML, Sassaki CM, Oliveira MF, Villa TC, dos Santos CB. Time series of tuberculosis 
mortality in Brazil (1980-2001). Rev Lat Am Enfermagem. 2007;15(5):936-41. http://dx.doi.org/10.1590/ S0104-11692007000500009

20. Kayigamba FR, Bakker Ml, Mugisha V, De Naeyer L, Gasana M, Cobelens F, et al. Adherence to tuberculosis treatment, sputum smear conversion and mortality: a retrospective cohort study in 48 Rwandan clinics. PLoS One. 2013;8(9):e73501. http://dx.doi.org/10.1371/ journal.pone.0073501

21. Alavi-Naini R, Moghtaderi A, Metanat M, Mohammadi $\mathrm{M}$, Zabetian M. Factors associated with mortality in tuberculosis patients. J Res Med Sci. 2013;18(1):52-5.

22. Álvarez JL, Kunst AE, Leinsalu M, Bopp M, Strand BH, Menvielle G, et al. Educational inequalities in tuberculosis mortality in sixteen European populations. Int J Tuberc Lung Dis. 2011;15(11):1461-7. http://dx.doi.org/10.5588/ ijtld.10.0252

23. Jung RS, Bennion JR, Sorvillo F, Bellomy A. Trends in tuberculosis mortality in the United States, 1990-2006: a population-based case-control study. Public Health Rep. 2010;125(3):389-97

24. Holmes CB, Hausler H, Nunn P. A review of sex differences in the epidemiology of tuberculosis. Int $\mathrm{J}$ Tuberc Lung Dis. 2008;2(2):96-104.
25. Façanha MC. Evolução da mortalidade por tuberculose em Fortaleza (CE), entre 1980 e 2001. J Bras Pneumol. 2006;32(6):553-8. http://dx.doi.org/10.1590/ S1806-37132006000600013

26. Selig L, Kritski AL, Cascão AM, Braga JU, Trajman A, de Carvalho RM. Proposal for tuberculosis death surveillance in information systems. Rev Saude Publica. 2010;44(6):1072-8. http://dx.doi.org/10.1590/ S0034-89102010000600012

27. Joaquim AF, Carandina L, Defaveri J. Tuberculose em necropsias realizadas no Serviço de Anatomia Patológica da Faculdade de Medicina de Botucatu. J Bras Patol Med Lab. 2006;42(3):193-200. http://dx.doi.org/10.1590/ S1676-24442006000300008

28. Curtis S. Health and Inequality: Geographical Perspectives. London: Sage Publications; 2009.

29. Pereira PR, Cutrim Jr V, Rodrigues ZM. Desigualdades intraurbanas dos indicadores de saneamento em São Luís - MA [monograph on the Internet]. São Luís: Universidade Federal do Maranhão; 2013 [cited 2014 Jun 02]. [Adobe Acrobat document, 10p.]. Available from: http://www. joinpp.ufma.br/jornadas/joinpp2013/JornadaEixo2013/ anais-eixo 13-questaourbanaegestaodascidades/ desigualdadesintraurbanasdosindicadoresdesaneamento.pdf

\section{About the authors}

Marcelino Santos-Neto

Professor. Nursing School, Federal University of Maranhão at Imperatriz, Imperatriz, Brazil.

\section{Mellina Yamamura}

Doctoral Student of Science. Program of Nursing in Public Health, University of São Paulo at Ribeirão Preto School of Nursing, Ribeirão Preto, Brazil.

\section{Maria Concebida da Cunha Garcia}

Doctoral Student of Science. Program of Nursing in Public Health, University of São Paulo at Ribeirão Preto School of Nursing, Ribeirão Preto, Brazil.

\section{Marcela Paschoal Popolin}

Doctoral Student of Science. Program of Nursing in Public Health, University of São Paulo at Ribeirão Preto School of Nursing, Ribeirão Preto, Brazil.

\section{Tatiane Ramos dos Santos da Silveira}

Computer Science Technologist. University of São Paulo at Ribeirão Preto School of Nursing, Ribeirão Preto, Brazil.

\section{Ricardo Alexandre Arcêncio}

Professor. Department of Maternal and Child Health and Public Health, University of São Paulo at Ribeirão Preto School of Nursing, Ribeirão Preto, Brazil. 